\title{
Identification of Characters Correlated with Tuber Yield in Guinea White Yam (Dioscorea rotundata Poir)
}

Keywords: Dioscorea rotundata; Character relationship; Tuber yield; Yield components; Yield improvement

\begin{abstract}
A study was conducted in 2016 cropping season in two locations (Itu and Uyo) in Akwa Ibom State, Nigeria to assess characters associated with fresh tuber yield in guinea white yam. The positive and highly significant correlations $(p<0.01)$ were established between fresh tuber yield and seven primary yield components in yam, namely number of ware yam per hectare $(r=0.814)$, fresh weight of ware yam per plant $(r=0.868)$, fresh weight of seed yam per hectare $(r=0.736)$, fresh weight of ware yam per hectare $(r=0.751)$, fresh weight of yam per plant $(r=0.986)$, circumference of tubers $(r=0.879)$ and length of tubers $(r=0.728)$, while positive and significant correlation $(p<0.05)$ was established between fresh tuber yield and vine length $(r=0.541)$. This study provides strong evidence that the yield parameters having important contributory factors to tuber yield should be considered in breeding and selection for higher tuber yield in guinea white yam. However, the negative correlation observed between fresh tuber yield and number of leaves per plant shows that number of leaves though an important morphological character is not a major contributory factor to yield in guinea white yam.
\end{abstract}

\section{Abbreviations}

NSYP: Number of Seed Yam per Plot; NSYH: Number of Seed Yam per Hectare; NWYH: Number of Ware Yam per Hectare; FWSYP: Fresh Weight of Seed Yam per Plot; FWWYP: Fresh Weight of Ware Yam per Plot; FWSYH: Fresh Weight of Seed Yam per Hectare; FWYH: Fresh Weight of Ware Yam per Hectare; FWYP: Fresh Weight of Yam per Plot; FTYH: Fresh Tuber Yield per Hectare; CT: Circumference of Tubers; LOT: Length of Tubers; NLPP: Number of Leaves per Plant; VL: Vine Length, LA: Leaf Area; NBPP: Number of Branches per Plant

\section{Introduction}

Yam (Dioscorea spp) is generally classified under the genus Dioscorea, family Diocoreaceae and order Dioscoreales. The most important species of Dioscorea include Dioscorea rotundata (guinea white yam), Dioscorea cayenensis (guinea yellow yam), Dioscorea dumetorum (three leaved yam), Dioscorea esculenta (lesser yam or Chinese yam), Dioscorea bulbifera (aerial yam) and Dioscorea alata (water yam or greater yam) [1-3]. Yam is the second most important tuber crop in the world after cassava in terms of production. Dioscorea rotundata is the most widely grown and eaten yam species in Nigeria and indeed, most important in the world. It forms an important staple food source in tropical and sub-tropical countries including West Africa, East Africa, Caribbean, South America, India, Southeast Asia and South Pacific [4]. However, West Africa remains the most important yam producing region of the world [5]. The fleshy

\section{Journal of Plant Biology \& Soil Health}

\section{Emmanuel E. Bassey* and Gamaliel I. Harry}

Department of Crop Science, Faculty of Agriculture, University of Uyo, Nigeria

\section{Address for Correspondence}

Emmanuel E. Bassey, Department of Crop Science, Faculty of Agriculture, University of Uyo, Uyo, Nigeria, Tel: +2348024686153; E-mail: emmanuelessien@rocketmail.com

Submission: 06 May, 2017

Accepted: 20 June, 2017

Published: 29 June, 2017

Copyright: (c) 2017 Bassey EE, et al. This is an open access article distributed under the Creative Commons Attribution License, which permits unrestricted use, distribution, and reproduction in any medium, provided the original work is properly cited.

harvested yam tubers contain about 70\% water, 25\% starch, $1 \%-2 \%$ protein and only traces of sugars. Yam tubers are good energy sources and the energy is derived mainly from carbohydrate, since the tubers are low in fats. Yam is also rich in three minerals, namely calcium, phosphorus and iron. The vitamin contents of yam tubers include carotene (pro-vitamin A), thiamine, riboflavin, niacin and ascorbic acid. Average yam consumption per capita per day is highest in Benin (364 kcal), followed by Cote d'Ivoire (342 kcal), Ghana ( $296 \mathrm{kcal})$ and Nigeria (258 kcal) [6]. Nigeria is the largest world producer of yam with more than 45.004 million metric tonnes ( $\mathrm{mmt}$ ) annually and the largest consumer of yam with Ghana $(7.119 \mathrm{mmt})$, Cote d'Ivoire (5.808 mmt), Benin Republic (3.220 mmt), Ethiopia (1.448 mmt), Togo $(0.786 \mathrm{mmt})$ and Cameroon $(0.579 \mathrm{mmt})$ following that order [7,8]. Yam contributes more than 200 dietary calories per day for over 60 million people in Nigeria [9]. In many yam producing areas in Nigeria, "yam is food and food is yam". It is the only crop which is usually celebrated during and after harvest, called yam festival [10].

Yield of about $11.0 \mathrm{t} / \mathrm{ha}$ on average has been obtained in major yam producing countries of West Africa [11]. Higher yields of more than $29.6 \mathrm{t} / \mathrm{ha}$ have been reported under good management [12]. Yam is produced in more than 47 countries of the world [9]. Due to its importance, new lines of guinea white yam have been released by several West African countries. However, there is need to understand the yield contributory traits in yam and incorporate them in yield improvement. Low rate of growth and yield of yam due to degraded soil and increasing levels of field and storage pests and diseases are the possible reasons for low patronage given to yam compared to cassava production in Nigeria $[6,13]$.

Yield is a complex quantitative character controlled by several genes, which rather exist in yield components [14]. Yield components have been used in reference to those plant characters that are closely associated with yield rather than yield itself [15]. Yield is a final product which results from interaction of several developmental and biochemical processes and therefore has large environmental and genetic components [16]. It is obvious from this consideration that there are no genes for yield per se, genes exist only for the primary yield components [17]. 
Citation: Bassey EE, Harry GI. Identification of Characters Correlated with Tuber Yield in Guinea White Yam (Dioscorea rotundata Poir). J Plant Biol Soil Health. 2017;4(1): 5.

\section{ISSN: 2331-8996}

The quality of primary yield components in a crop and their inheritance pattern can lead to simple and more reliable conclusion about gene action than the study of the yield. No real advantage would be gained from the yield component analysis if it is discovered that the primary yield components are negatively correlated with the yield [17]. Determination of the relationship between yield and various yield contributory characters and using the information to work out the most efficient combination of characters will give maximum advantage in yield when used in selection programmes. The most promising hybrids, lines and varieties have been tested for yield potentials and efficiency of yield components in different environments. The relationship between the various components and yield is measured quantitatively in terms of coefficient of correlation which is the ratio of the average product of deviation of $\mathrm{x}$ and $\mathrm{y}$ to the product of their standard deviation. The use of coefficient of correlation (r) assumes that there is a linear relationship between yield components and yield [16]. Correlation measures the mutual association between components, without regards to causation and it is necessary for selection of parents in breeding programmes [18].

Genetic improvement in yam is aimed at increasing tuber yield which is considered a major focus of interest [19]. Improvement of food yam has been possible due to the collaborative efforts of the National Root Crops Research Institute, Umudike, with the International Institute of Tropical Agriculture, Ibadan both in Nigeria in areas of interspecific hybridization and production of hybrid yam varieties for commercial production [20]. The flowering behaviour in relation to artificial pollination in yam has been better understood, selection for high tuber yield and other desirable tuber characteristics as well as adaptation to different ecological zones in Nigeria have been well studied [21].

However, not much work has been done on character relationship and association with tuber yield in guinea white yam in order to provide guide posts for development of high yielding varieties and avert more declining growth rate in yam production in Nigeria [22]. There is need to understand the character relationship among yam genotypes, identify traits that determine tuber yield and find out the influence of other traits associated with yield. Estimates of phenotypic correlation among characters are useful in planning and evaluating breeding programmes. It aids in ascertaining if improvement in one character would simultaneously result in changes in other characters among yam genotypes in a given environment. Therefore, information on correlation is of much use in breeding for increased yield potential in yam. Selection of suitable yam genotypes from existing ones could be an important aspect of improvement if their physiological characters and yield components correlate positively and significantly with tuber yield [23]. This study was therefore conducted to assess the character relationship and their associations with tuber yield and identify characters which are positively and significantly correlated with tuber yield in guinea white yam.

\section{Materials and Methods}

The study was conducted in 2016 cropping season in two locations (Itu and Uyo) in Akwa Ibom State, Nigeria to assess the character relationship and their association with tuber yield and identify characters that are positively and significantly correlated with tuber yield in guinea white yam.
The areas lie within latitude $15^{\circ} 02^{\prime}$ north and longitude $07^{\circ} 56^{\prime}$ east of the Greenwich meridian, and altitude $38 \mathrm{~m}$ above sea level. The areas lie in the high humid rainforest zone of Southeastern Nigeria with an average rainfall of over $2500 \mathrm{~mm}$ per annum and mean daily sunshine of 3.5 hours. The temperature is generally high, ranging from $23{ }^{\circ} \mathrm{C}$ to $34{ }^{\circ} \mathrm{C}$ throughout the year. The average humidity is about $76 \%$ with the lowest and highest in January/December and July, respectively [24]. The site had a fairly flat terrain. Soil samples were randomly collected with soil auger at depths $0-15 \mathrm{~cm}$ and $15-30$ $\mathrm{cm}$. The samples were air dried, crushed gently with wooden pestle in a porcelain mortar and sieved through a $2 \mathrm{~mm}$ sieve. The samples were bulked and a representative sample of each site was analyzed for physico-chemical properties as an aid to fertilizer application.

The treatments were sixteen guinea white yam (Dioscorea rotundata) genotypes comprising fourteen (14) advanced guinea white yam lines, namely 99/AMO/XA, 99/AMO/116, 98/00933, Nwakpoko, 07/00168, Obiauturugo, 99/AMO/109, Adaka, 99/ AMO/95A, 99/AMO/114, 00604, 99/AMO/60, AME and 07/00033 with $98 / 02665$ as national check were obtained from the National Root Crops Research Institute, Umudike, Nigeria. A local cultivar, UL-A-1 (Akpedu) obtained from Uyo and Itu yam farmers served as local check.

Sixteen genotypes of yam were cut into minisetts of $40 \mathrm{~g}$, each genotype comprised 30 yam minisetts which were properly labelled and spread under shade for two days [7,25]. Each experimental site required 480 minisetts, giving a total of 960 minisetts for the two experimental sites. Each experimental site measured $17 \mathrm{~m} \times 16 \mathrm{~m}$ which was ploughed, harrowed and ridged $1 \mathrm{~m}$ apart and $0.5 \mathrm{~m}$ high. The experiment was laid out in a randomized complete block design with three replications. Each ridge (plot) measured $5 \mathrm{~m}$ long and the blocks were separated by $1 \mathrm{~m}$ paths. One yam minisett (40 g) was planted per stand at $0.5 \mathrm{~m}$ by $1 \mathrm{~m}$, giving 10 plants per ridge and 480 plants for one experimental site, equivalent to 20,000 plants per hectare. Staking was done 25 days after planting using Indian bamboo which measured $2 \mathrm{~m}$ [26]. Weeding was done manually using the West African hoe at 1, 3 and 5 months after Planting (MAP) Fertilizer NPK (15:15:15) was applied $1 \mathrm{MAP}$ at $400 \mathrm{~kg} / \mathrm{ha}, 10 \mathrm{~cm}$ away from the yam plant, using the ring method $[27,28]$.

Four plants were randomly selected at the centre of each plot and tagged for data collection. Growth characters studied were vine length $(\mathrm{cm})$, number of leaves per plant, number of branches per plant, and leaf area $\left(\mathrm{cm}^{2}\right)$. Yield and yield components studied were number of seed yam per plot, number of seed yam per hectare, number of ware yam per hectare, fresh weight of seed yam per plot, fresh weight of ware yam per plot, fresh weight of seed yam per hectare, fresh weight of ware yam per hectare, fresh weight of yam per plot, fresh tuber yield per hectare, circumference of tubers and length of tubers. Leaf area was determined as $\mathrm{L} \times \mathrm{W} \times 0.43$, where, $\mathrm{L}=$ mean length of yam leaves; $\mathrm{W}=$ mean widest portion of yam leaves; $0.43=$ the correction factor [29]. Means of characters from the two locations were used in correlation analysis.

Phenotypic correlation for each character was based on the Pearson Product Moment Correlation Coefficient using the procedure described by Wahua [30]. 
Citation: Bassey EE, Harry GI. Identification of Characters Correlated with Tuber Yield in Guinea White Yam (Dioscorea rotundata Poir). J Plant Biol Soil Health. 2017;4(1): 5 .

ISSN: $2331-8996$

\section{Results}

Significant character correlation was observed among the yield parameters and vine length in guinea white yam (Table 1). The result showed that number of seed yam per plot correlated positively and significantly $(\mathrm{p}<0.01)$ with number of seed yam per hectare. Similarly, number of seed yam per plot correlated positively and significantly $(\mathrm{p}$ $<0.05)$ with fresh weight of seed yam per hectare. Number of seed yam per hectare was negatively and not significantly correlated $(\mathrm{p}<$ 0.05 ) with number of ware yam per hectare, fresh weight of ware yam per plot, total ware yam per hectare, length of tubers and number of leaves per plant. However, number of ware yam per hectare showed a strong positive correlation $(\mathrm{p}<0.01)$ with fresh weight of ware yam per plot $(r=0.989)$, ware yam per hectare $(r=0.899)$, fresh weight of yam per plot $(r=0.814)$, fresh tuber yield per hectare $(r=0.814)$, length of tubers $(r=0.890)$, circumference of tubers $(r=0.687)$ and vine length (0.567). However, number of ware yam per hectare was negatively though not significantly correlated with fresh weight of seed yam per plot $(\mathrm{r}=-0.008)$, and number of leaves per plant $(\mathrm{r}=$ $-0.145)$. Fresh weight of seed yam per plot was significantly correlated $(\mathrm{p}<0.05)$ with fresh weight of seed yam per hectare $(r=0.602)$ but negatively correlated $(\mathrm{p}<0.05)$ with fresh weight of ware yam per plot $(\mathrm{r}=-0.036)$, fresh weight of ware yam per hectare $(r=-0.072)$, length of tubers $(r=-0.051)$ and number of leaves per plant $(r=-0.313)$.

Fresh weight of ware yam per plot was highly $(\mathrm{p}<0.01)$ correlated with fresh weight of ware yam per hectare $(r=0.945)$, fresh weight of ware yam per plot $(\mathrm{r}=0.868)$, fresh tuber yield per hectare $(\mathrm{r}=0.868)$, circumference of tubers $(r=0.730)$, length of tubers $(r=0.881)$ and positively and significantly correlated $(p<0.05)$ with vine length $(r=$ $0.524)$ though negatively correlated with number of leaves per plant $(-0.161)$.

Fresh weight of seed yam per hectare was highly significant and positively correlated $(\mathrm{p}<0.01)$ with fresh weight of ware yam per hectare $(r=0.767)$, fresh weight of yam per plot $(r=0.767)$ and fresh tuber yield per hectare $(r=0.525)$, though negatively correlated with number of leaves per plant $(r=-0.364)$. Fresh weight of ware yam per hectare was strongly and significantly $(\mathrm{p}<0.01)$ correlated with fresh weight of yam per plot $(r=0.901)$, fresh tuber yield per hectare $(r=$ $0.751)$ and circumference of tubers $(r=0.813)$, but negatively, though not significantly with length of tubers $(r=-0.135)$. Fresh weight of yam per plot was positively and significantly correlated $(\mathrm{p}<0.01)$ with fresh tuber yield per hectare $(r=0.986)$, circumference of tubers $(r=0.879)$ and length of tubers $(r=0.728)$, but negatively correlated with number of leaves per plant $(r=-0.269)$.

Relation between yield and some yield related characters was observed among the genotypes tested. Accordingly, fresh tuber yields were strongly and highly significant $(\mathrm{p}<0.01)$ for most of the yield parameters, namely number of ware yam per hectare $(r=0.814)$, fresh weight of ware yam per plot $(r=0.868)$, fresh weight of seed yam per hectare $(r=0.736)$, fresh weight of ware yam per hectare $(r=0.751)$, fresh weight of yam per plot $(r=0.986)$, circumference of tubers $(r=0.879)$, length of tubers $(r=0.728)$ and vine length $(r$ $=0.541)$. Results showed that significant correlation $(\mathrm{p}<0.01)$ exist between fresh tuber yield and most of the yield parameters in yam (Table 1). Fresh weight of yam had the highest correlation coefficient with tuber yield $(\mathrm{r}=0.986)$, followed by circumference of tubers $(r=0.879)$, fresh weight of ware yam per plot $(r=0.868)$, number of ware yam per hectare $(r=0.814)$, fresh weight of ware yam per hectare $(r=0.751)$, fresh weight of seed yam per hectare $(r=0.736)$, length of tubers $(r=0.728)$ and vine length $(r=0.541)$, but negatively correlated with number of leaves per plant $(r=-0.268)$ (Table 1). Similarly, circumference of tubers was positively and significantly correlated with length of tubers $(r=0.681)$ and number of branches per plant $(r=0.562)$, though negatively correlated with number of leaves per plant $(r=-0.393)$. The result also showed that length of tubers was positively and significantly correlated $(\mathrm{p}<0.05)$ with vine length $(r=0.597)$ but negatively correlated with number of leaves per plant $(r=-0.040)$.

Table 1: Simple correlation coefficient between agronomic traits and fresh tuber yield of yam genotypes in 2016.

\begin{tabular}{|c|c|c|c|c|c|c|c|c|c|c|c|c|c|c|c|}
\hline \multirow[b]{2}{*}{ Characters } & \multicolumn{15}{|c|}{ Correlations } \\
\hline & NSYP & NSYH & NWYH & FWSYP & FWWYP & FESYH & WYH & FWYP & FTYH & CT & LOT & NLPP & VL & LA & NBPP \\
\hline NSYP & 1 & 0.998 & -0.160 & 0.440 & -0.143 & 0.550 & -0.090 & 0.199 & 0.199 & 0.149 & -0.295 & -0.448 & 0.039 & 0.062 & 0.253 \\
\hline $\mathrm{NSYH}$ & & 1 & 0.174 & 0.430 & -0.157 & 0.538 & -0.102 & 0.185 & 0.185 & 0.128 & -0.315 & -0.462 & 0.044 & 0.058 & 0.246 \\
\hline NWYH & & & 1 & -0.008 & $0.989^{* *}$ & 0.379 & $0.899^{* *}$ & $0.814^{* *}$ & $0.814^{* *}$ & $0.687^{* *}$ & $0.890^{* *}$ & -0.145 & $0.567^{*}$ & 4.15 & 0.234 \\
\hline FWSYPP & & & & 1 & -0.036 & $0.602^{*}$ & -0.072 & 0.236 & 0.236 & 0.387 & -0.059 & -0.313 & 0.263 & 0.026 & 0.270 \\
\hline FWWYPP & & & & & 1 & 0.405 & $0.945^{*}$ & $0.868^{* *}$ & $0.868^{* *}$ & $0.730^{* *}$ & $0.881^{* *}$ & -0.161 & $0.524^{*}$ & 0.395 & 0.279 \\
\hline FWSYH & & & & & & 1 & 0.413 & $0.767^{* *}$ & $0.767^{\star *}$ & $0.736^{* *}$ & 0.328 & -0.364 & $0.525^{\star}$ & 0.184 & 0.313 \\
\hline FWYH & & & & & & & 1 & $0.901^{* *}$ & $0.901^{* *}$ & $0.751^{* *}$ & $0.813^{\star *}$ & -0.135 & 0.413 & 0.458 & 0.295 \\
\hline FWYP & & & & & & & & 1 & 0.986 & $0.879^{* *}$ & $0.728^{* *}$ & -0.269 & $0.541^{*}$ & 0.410 & 0.357 \\
\hline FTYH & & & & & & & & & 1 & $0.879^{* *}$ & $0.728^{* *}$ & -0.268 & $0.541^{*}$ & 0.411 & 0.357 \\
\hline CT & & & & & & & & & & 1 & $0.681^{* *}$ & -0.393 & 0.345 & 0.406 & $0.562^{*}$ \\
\hline LOT & & & & & & & & & & & 1 & -0.040 & $0.597^{*}$ & 0.337 & 0.202 \\
\hline NLPP & & & & & & & & & & & & 1 & -.218 & -0.330 & -0.443 \\
\hline VL & & & & & & & & & & & & & 1 & 0.118 & -0.076 \\
\hline NBPP & & & & & & & & & & & & & & & 1 \\
\hline
\end{tabular}

${ }^{* *}$ Correlation is significant at the 0.01 level (2-tailed)

${ }^{*}$ Correlation is significant at the 0.05 level (2-tailed) 
Citation: Bassey EE, Harry GI. Identification of Characters Correlated with Tuber Yield in Guinea White Yam (Dioscorea rotundata Poir). J Plant Biol Soil Health. 2017;4(1): 5.

ISSN: $2331-8996$

\section{Discussion}

Yam improvement aims at increasing tuber yield to meet with the current demands and possibly export the surplus for foreign exchange earnings. Increase in yield would therefore require a proper understanding of character relationship and its effect on tuber yield and application of such information in improvement and selection in yam. Lack of positive and significant correlation between fresh tuber yield and number of leaves per plant in this study showed that number of leaves per plant should not be considered as a direct indicator or yield component of tuber yield in yam. Several studies on other tuber crops tend to show similar results. For example, Okpara et al. observed no correlation response between number of leaves and storage root yield in cassava [31]. Similarly Bassey established no significant correlation between number of leaves per vine and fresh tuber yield in sweetpotato. However, in a study of source-sink relationship in cassava, Bassey and Harry considered the power of the source, rather than number of leaves as a major determinant of photosynthate, which may correlate with the sink capacity in cassava $[32,33]$. Negative correlation between plant characters and tuber yield has been reported to create obstacles to yield improvement [34]. In this study, positive and significant correlations $(\mathrm{p}<0.01)$ were established between fresh tuber yield and seven primary yield components in yam, namely number of ware yam per hectare $(r=0.814)$, fresh weight of ware yam per plant $(r=0.868)$, fresh weight of seed yam per hectare $(r=0.736)$, fresh weight of ware yam per hectare $(r=0.751)$, fresh weight of yam per plant $(\mathrm{r}=0.986)$, circumference of tubers $(\mathrm{r}=$ $0.879)$ and length of tubers $(r=0.728)$, while positive and significant correlation $(\mathrm{p}<0.05)$ was established between fresh tuber yield and vine length in yam $(r=0.541)$. The result of the study provides evidence that these yield parameters are important contributory factors to yield in yam and should therefore be considered in the breeding and selection for higher yields in yam. Chopra reported that correlation helps to establish associations among characters in field research and identify characters which associate significantly and improve crop yields [35]. Similarly, Bashiru et al. reported that data on the nature of inter-relationship among plant characters and with yield could help in formulating efficient schemes for multiple trait selection in crops [36].

Therefore, improvement in those characters may result in higher tuber yields in yam in Nigeria to meet the current demands. However, the characters which are negatively correlated with tuber yield should not be considered for future breeding programmes for yam improvement. Correlation studies could also help to reveal characters which are negatively correlated with tuber yield and thus reduce costs of breeding and eliminate other obstacles associated with yield improvement [34].

\section{Conclusion}

The result of this study is vital to the screening and breeding of guinea white yam for higher yields in Nigeria. The yield parameters, namely, number of ware yam per hectare $(r=0.814)$, fresh weight of ware yam per plant $(r=0.868)$, fresh weight of seed yam per hectare $(r=0.736)$, fresh weight of ware yam per hectare $(r=0.751)$, fresh weight of yam per plant $(r=0.986)$, circumference of tubers ( $r$ $=0.879)$ and length of tubers $(r=0.728)$, which are positively and highly correlated $(\mathrm{p}<0.01)$ with tuber yield in yam, and called the primary yield components demand close attention and consideration in yield improvement in guinea white yam. However, the negative correlation observed between fresh tuber yield and number of leaves per plant indicates that number of leaves per plant though an important morphological character is not a major contributory factor to yield in guinea white yam.

\section{References}

1. Ashun MD, Acheampong $E$ (1998) Effect of age on in vitro culture post flask management of the three Dioscorea species. Proceedings of the $7^{\text {th }}$ Triennial Symposium of the International Society for Tropical Root Crops Africa Branch (ISTRC-AB). In: Akoroda MO, Ngeve JM (Eds), Root crops in 21st century. Centre International des Conférences, Cotonou, Benin, 11-17 October, Africa, pp. 472-477.

2. Chadha KL (2006) Handbook of horticulture, (5thedn). Directorate of Information and Publications of Agriculture, Indian Council of Agricultural Research (ICAR), New Delhi, India, pp. 1031.

3. Okonkwo SN (1985) Botany of the yam plant and its exploitation in enhanced productivity of the crop. In: Osunji G (Ed.), Advances in yam research: the biochemistry and technology of the yam tuber. Biochemical Society of Nigeria and Anambra State University of Technology, Enugu, Nigeria, pp. 3-29.

4. International Institute of Tropical Agriculture (2013) Report, achievements, challenges and prospects of yam production in Nigeria. International Institute of Tropical Agriculture, Ibadan, Nigeria, pp. 8-10.

5. Ekpe EO, Chinaka CC, Otto E, Okoko ES, Emah VE (2005) Comparative evaluation of bulbils and sett sizes on growth pattern and yield of water yam (Dioscorea alata L.). Niger J Agric Food Environ 2: 42-46.

6. International Institute of Tropical Agriculture (2009) Annual report 2009/10. International Institute of Tropical Agriculture, Ibadan, Nigeria.

7. Ezulike TO, Udealor A, Nwosu KI, Asumugha GN (2006) Rapid multiplication of seed yam by minisett technique. Extension Guide No. 15, Extension Service Programme, National Root Crops Research Institute, Umudike, Nigeria, pp. 1-10.

8. FAO (2014) Top 10 Yam Producing Countries. Food and Agriculture Organisation, Rome, Italy.

9. Nweke FI, Ugwu BO, Asiedu CL, Ay P (1991) Production cost of yam based cropping system in Southeastern Nigeria. RCMD research monograph no. 6, International Institute of Tropical Agriculture, Ibadan, Nigeria, pp. 6-8.

10. Ugwu BO (1996) Yam and cassava production as income-generating activities for households. Afr J Root Tuber Crops 1: 43-48.

11. Food and Agriculture Organisation (2005) Production yearbook. Food and Agriculture Organisation, Rome, Italy.

12. Adeniji MO, Obigbesan GO, Asiedu R, Bokanga M (1998) Influence of fertilizers on yield, storage and food qualities of yams. Proceedings of the $7^{\text {th }}$ Triennial Symposium of the International Society for Tropical Root Crops - Africa Branch (ISTRC-AB). In: Akoroda MO, Ngeve JM (Eds), Root crops in $21^{\text {st }}$ century. Centre International des Conférences, Cotonou, Benin, 11-17 October, Africa, pp. 307 - 310

13. Dansi A, Mignouna HD, Sangare A, Zoundjih J, Kpon, et al. (2001) Characterisation and conservation of yam biodiversity for sustainable use for food and agriculture in Benin Republic. Proceedings of the $7^{\text {th }}$ Triennial Symposium of the International Society for Tropical Root Crops - Africa Branch (ISTRC-AB). In: Akoroda MO, Ngeve JM (Eds), Root crops in 21st century. Centre International des Conférences, Cotonou, Benin, 11-17 October, Africa, pp. 424-429.

14. Mahungu NM (1983) Relationships among selected agronomic characters and their effects on storage root yield of cassava (Manihot esculenta Grants). Ph.D Thesis, University of Ibadan, Nigeria, pp. 193-198.

15. Eka MJ (1989) Analysis of yield components of three cultivars of water melon (Citrullus lanatus Schrad) under the tropical rainforest conditions of Calabar in Southeastern Nigeria, Ph.D Thesis, University of Calabar, Nigeria, pp. 4593. 
Citation: Bassey EE, Harry GI. Identification of Characters Correlated with Tuber Yield in Guinea White Yam (Dioscorea rotundata Poir). J Plant Biol Soil Health. 2017;4(1): 5 .

16. Ebong UU, Nwonuala A (1997) Plant Breeding-Advanced Breeding Topics. Best Bets Publishers, Port Harcourt, Nigeria, pp. 42-45

17. Bassey EE (2008) Field evaluation and diallel analysis of metric traits in Okra (Abelmoschus esculentus (L.) Moench) under the tropical rainforest environment of Southeastern Nigeria, Ph.D Thesis (unpublished), Department of Agronomy, Michael Okpara University of Agriculture, Umudike, Nigeria, pp. 162-167.

18. Eleweanya NP, Uguru MI, Eneobong EE, Okocha PI (2005) Correlation and path coefficient analyses of grain yield related characters in maize (Zea mays L.) under Umudike conditions of South Eastern Nigeria. J Agric Food Environ Ext 4: 24-28.

19. Aina OO, Dixon AG, Akinrinde EA (2007) Trait association and path analysis for cassava genotypes in four agroecological zones of Nigeria. J Biol Sci 7: 759-764.

20. National Centre for Genetic Resources and Biotechnology (2004) Crop varieties released and registered in Nigeria. National Centre for Genetic Resources and Biotechnology, Moore Plantation, Ibadan, Nigeria, pp. 39-40.

21. Nwankwo II, Eka MJ, Bassey EE, Nwachukwu EC (2011) Flowering behaviour and physiological characteristics of intra-specific hybrids of Dioscorea rotundata, Poir in humid environment of Southeastern Nigeria. Niger J Agric Food Environ 7: 16-21.

22. Central Bank of Nigeria (2012) Central Bank of Nigeria Annual Report Central Bank of Nigeria, Garki, Abuja, Nigeria, pp. 159-160.

23. Gargi DS, Porwal R, Sharma RK (2013) Studies on growth, yield and tube characteristics of sweet potato varieties. Progress Res 8: 667-868.

24. Ekpeh IJ (1994) Physiography, climate and vegetation in Akwa Ibom State. In: Petters SW, Iwok ER, Uya OE (Eds), Akwa Ibom State: the land of promise, a compendium. Gabumo Publishing Co., Lagos, Nigeria, pp. 377.

25. Timothy GE, Bassey EE (2009) Preliminary study on the effect of tuber settweight derived from regions of seed yam on growth and yields of yam in
Southeastern Nigeria. Niger J Agric Technol 14: 6-12.

26. Uguru MI (1996) Crop production: tools, techniques and practice. Fulladu Publishing Co., Nsukka, Nigeria, pp. 1-147.

27. National Root Crops Research Institute (2016) National Root Crops Programme (NRCP) protocol - evaluation of advanced white yam lines. National Root Crops Research Institute, Umudike, Nigeria, pp. 1-3.

28. Udealor A Ezulike TO (2009) On-farm evaluation of the performance of new yam minisett sizes for increased adoption. Niger Agric J 40: 100-103.

29. Ravi B, Roy CS (1989) A method of leaf area determination in Dioscorea. J Root Crops 15: 45-48.

30. Wahua TA (1999) Applied statistics for scientific studies. Africa-Links Books, Owerri, Nigeria, pp. 68-70.

31. Okpara DA, Mbah EU, Chukwu EI (2014) Assessment of growth and yield of some high-and-low-cyanide cassava genotypes in acid ultisols of South Eastern Nigeria. Afr J Biotechnol 13: 651-656.

32. Bassey EE (2017) Variability in the yield and character association in Nigerian sweet potato (Ipomoea batatas (L.) Lam) genotypes. World J Agric Sci 5: 66-74

33. Bassey EE, Harry GI (2013) Screening cassava (Manihot esculenta Crantz) genotypes for tuber bulking, early maturity and optimum harvesting time in Uyo, Southeastern Nigeria. Peak J Agricultural Sci 1: 83-88.

34. Adams MW (1967) Basis of yield component compensation in crop plants with special reference to the field bean, Phaseolus vulgaris. Crop Sci 7: 505510.

35. Chopra VL (2001) Breeding field crops. India Book House Pvt Ltd, New Delhi, India, pp. 442-443.

36. Bashiru F, Zeleke H, Woldsadik H (2008) Genetic variability for seed yield and other agronomic traits in some Ethiopian Fenugreek (Trigonella foenumgraecum L.) land races. Int J Pure Appl Sci 1: 55-61. 